\title{
Disaggregate Energy Consumption and Sectoral Output in Nigeria
}

\author{
Nwosa Philip Ifeakachukwu \\ Department of Economics and Development Studies, Faculty of Social Sciences, Federal University Oye-Ekiti, Oye-Ekiti, Nigeria
}

\section{Email address:}

nwosaphilip@yahoo.com

\section{To cite this article:}

Nwosa Philip Ifeakachukwu. Disaggregate Energy Consumption and Sectoral Output in Nigeria. Science Journal of Energy Engineering. Vol. 5, No. 6, 2017, pp. 136-145. doi: 10.11648/j.sjee.20170506.12

Received: October 25, 2016; Accepted: March 23, 2017; Published: November 28, 2017

\begin{abstract}
This study examined the nexus between components of aggregate energy consumption and sectoral output in Nigeria for the period spanning 1980 to 2014. Sequel to the unit root and co-integration estimates, the study utilized the Vector Auto-regressive (VAR) and Vector Error Correction (VEC) techniques. Thus, the study observed that the direction of causation between components of energy consumption and output of individual sectors differed. The study recommended that energy policies should be sector specific, taking into cognizance the components of energy consumption influencing the output of individual sectors.
\end{abstract}

Keywords: Disaggregate Energy Consumption, Sectoral Output, VAR, VEC, Nigeria

\section{Introduction}

This dismal macroeconomic performance in major developed countries ensuing the energy crisis of the early 1970s has continued to raise pertinent question on the nature of the relationship between energy consumption and economic growth. Early studies in this regard have analysed this issue at the aggregate level, by focusing on the nexus between aggregate energy consumption and economic growth [1-10]. In recent times, studies have deviated from the aggregate analysis to considering the nexus between disaggregate energy consumption (such as gas, electricity, coal) and economic growth [11-18]. Apart from the above, studies have equally examined the nexus between aggregate energy consumption and sectoral output [19-21]. Despite plethora of literature on this issue, there has been a gross neglect on the empirical nexus between components of energy consumption and sectoral output.

Given that aggregate output (gross domestic product) is the summed outputs of the various sectors of the economy, these sectors could have been influenced differently by components of energy. Thus, it is erroneous to examine the nexus between aggregate energy consumption and aggregate output without a thorough understanding of the nexus between components of energy consumption and sectoral output; because key sectors of an economy that are dependent on specific components of energy consumption may have been overlooked in the aggregate analysis, especially if the aggregate analysis had revealed the absence of causation between the two aggregate variables. Therefore, energy conservation policies which are detrimental to the growth of these sectors might have been recommended based on the aggregate analysis.

With respect to the Nigerian economy, an empirical analysis on the nexus between components of energy consumption and sectoral output is important for the following reasons. One, in recent years, the Nigerian economy has witnessed an average growth rate of about 6.5 percent from 2001 to 2014, which undoubtedly is as a result of growth in some sectors of the economy (such as agriculture, service and others). The increase in sustained growth over this period could imply increased consumption of specific energy components in these sectors. It is therefore pertinent to explore this issue in order to avoid energy conservation policy that might be injurious to the growth of these sectors in particular and aggregate output in general. Two, as a way of ensuring that the current energy reform of the change agenda of the current administration does not toe the unenviable path of previous energy reforms introduced by predecessors' administrations, the findings of this study would enlighten the government and policymakers on the sectors of the economy in critical need of specific energy components. Furthermore, the findings of this study would aid the government in evolving future energy 
programmes that would accelerate sectoral output growth. Finally, endogenous studies [6, 11, 19, 22-23] like other studies in developed and developing countries have neglected this issue. This neglect could have mitigated the efficacy of the energy policy recommendations from previous studies on the growth of the economy.

It is against the above raised issues and the need to fill this gap in energy literature that this study sort to examine the direction of causation between components of energy consumption and sectoral output in Nigeria between from the period 1980 to 2014. In addition to the introduction, the rest of the paper is structured as follows. Section two presented a review of related studies while Section three discussed the methodology on which this study is based. Section four presented empirical analysis while section five provided the conclusion and policy recommendation of the study.

\section{Literature Review}

As pointed above, the nexus between energy consumption and economic growth has been studied by vast empirical studies. Starting with the pioneering study by [10] and using data on energy consumption and gross national product (a proxy for economic growth) of United States over the period from 1947 to 1974, the study observed a unidirectional causation between energy consumption and economic growth with causation running from economic growth to energy consumption. Consequent to this pioneered study, various study have examined this issue in different countries with differing periods and methodologies, using aggregate as well as disaggregate energy consumption. [20] examined the interdependence relationship between energy consumption and sectoral outputs in Pakistan for the period 1980 to 2007. The study utilized the Johansen-Juselisus co-integration approach and the Granger causality test. The co-integration estimate revealed that energy consumption exhibited long-run relationship with the agriculture as well as with services output. However, there is no evidence of long run relationship was observed between energy consumption and industrial output. Furthermore, the causality estimate revealed a bi-directional causal relationship between energy consumption and agriculture output while a unidirectional causation was observed from services and industrial output to energy consumption.

[22] examined the demand for energy at disaggregate level (gas, electricity and petroleum) for Nigeria over the period 1970-2007. Using a multivariate co-integration approach, the study revealed no evidence of long-run relationship between the energy sources and the per capita real income and domestic price. The short-run dynamics using the VAR analysis suggested that the average income elasticity of gas consumption is positive and higher than petroleum and electricity consumptions, making gas consumption more of a luxury than necessity. The study also observed that domestic price elasticity remained insignificant for the three energy sources. Furthermore, the result of the variance decomposition revealed that shocks to electricity and petroleum consumptions result mainly from disturbances in the production or supply of the products and not from domestic price and real income shocks.

[24] examined the relationship between disaggregate energy consumption and industrial output in Pakistan using annual data for the period 1972 to 2010. The study utilized the Johansen's multivariate co-integration approach and the Vector Error Correction Model (VECM) approach. The findings of the study revealed a positive effect of disaggregate energy consumption on industrial output. The VECM estimate showed that a bidirectional causality exist between industrial output and oil consumption, while unidirectional causation was observed from electricity consumption to industrial output. Also, a unidirectional causation was observed from industrial output to coal consumption while in the case of gas consumption, no causation was observed between gas consumption and industrial output. The study concluded that conservative energy policies could be harmful to the industrial production and therefore recommended the need for government to develop innovative energy policies in order to meet the demand for energy. In additional, the study also stress the need for the government to pay serious attention to alternative energy sources such as solar and wind in order to boost the clean industrial growth.

[19] examined nexus between aggregate energy consumption and sectoral output in Nigeria for the period 1980 to 2010. Utilizing a bi-variate Vector Auto-regressive (VAR) model, the study observed bi-directional causality between aggregate energy consumption and agricultural output while a unidirectional causality was found from service output to aggregate energy consumption. The concluded that the nexus between energy consumption and output of individual sectors of the economy are different and therefore recommended sector specific energy policies rather the one fit-for-all policy.

[25] examined the nexus between energy consumption (both aggregate and disaggregate energy component) and economic growth in Nigeria over the period 1970 to 2009. Utilizing the co-integration and granger causality tests, the study observed a unidirectional causality from petroleum, coal and electricity consumption to economic growth without any feedback. Also, bidirectional causality was observed between economic growth and gas consumption. The study concluded that energy consumption is an engine of growth for the Nigerian economy and therefore the neutrality hypothesis of energy consumption and economic growth is not supported by the study.

[12] examined the demand for energy at disaggregate level (gas, electricity and coal) for the Pakistan economy over the period 1972-2007. Using a multivariate co-integration approach, the study observed that electricity and coal consumption responded positively to changes in real income per capita and negatively to changes in domestic price level. The gas consumption responded negatively to real income and price changes in the short-run, however, in the long-run real income exerted a positive effect on gas consumption, while domestic price remained insignificant. Furthermore, the study revealed that in the short-run the average elasticities of price 
and real income for gas consumption (in absolute terms) were greater than those of electricity and coal consumption.

[21] examined the co-integration and causal nexus between energy consumption and sectoral output in Tunisia for the period 1971 to 2003. The sectors covered included agricultural; manufacturing, and services sector as well as the overall gross domestic product. Utilizing the Johansen's cointegration technique and the Vector Error Correction Model (VECM), the study observed that the various sectors (agriculture, manufacturing and service) and overall gross domestic product are co-integrated with energy consumption. This implies that there exists a long run relationship between the various output and energy consumption. The VECM estimate observed that there exist only a unidirectional causality running from the different sectors to energy consumption as well as from overall GDP growth to energy consumption. The study concluded that causality estimate signified a less energy dependent economy and suggested that it is sectoral growth that drives the energy consumption in Tunisia and not vice versa.

[26] examined the relationship between energy consumption and economic growth in Turkey for the period 1970 to 2003, using disaggregated data (oil and electricity). Applying the auto-regressive distributed lag approach, the study observed that in short run both oil consumption and electricity consumption has positive and statistically significant effect on economic growth. In long run, oil consumption was observed to have an insignificant positive effect on economic growth while electricity consumption had an insignificant negative effect on economic growth.

[27] examined the relationship between energy consumption and economic activity in Fiji for the period 1970 to 1994. Utilising a basic comparative statics approach, the energy use in the commercial and household sectors of Fiji's economy was decomposed into structural change effects, energy intensity effects and output growth effects. The analysis indicates that the rate of expansion of total energy use in the commercial sector was sharply reduced as a result of a structural change in the economy and an increase in the efficiency of energy use. The expansion in the rate of energy use in the household sector occurred mainly as a result of population increase, although inefficient energy use practices have also contributed to this growth in household consumption of energy.

[28] examined the effect of electricity consumption on economic growth in four South Asian countries, namely, Pakistan, India, Bangladesh and Sri Lanka for the period 1980 to 2010. The study utilized Pedroni's panel cointegration technique and the result of the study confirmed that there exists valid long-run relationship between electricity consumption and economic growth in South Asia. The results of random effects model suggested positive and significant impact of electricity consumption on economic growth in South Asian countries. The results of panel Granger causality test confirmed the unidirectional causal relationship runs from electricity consumption to economic growth. The study recommended that the South Asian countries should consider the development initiative and low-cost mode to produce electricity to enhance economic growth in the region.

[29] examined total energy consumption and its individual forms (oil, natural gas, electricity, renewable energies and coal) relationship with real gross domestic product (GDP) in Iran for the period 1967 to 2010. The study employed Hsiao's (1981) methodology and the result o the study showed a bidirectional causality effect with real GDP and total energy consumption as well as its three individual forms including, oil, natural gas and electricity. The result of the study no causality effect of other individual forms of energy such as renewable energies and coal with GDP.

[30] examined the causality between energy consumption and gross domestic product (GDP) in Tunisia for the period $1980-2012$. The focus of the study is to investigate empirically the relation of economic growth and energy consumption at both the aggregated and disaggregated levels regarding oil, natural gas, and electricity. The study employed vector error correction model and the results confirmed the existence of cointegration between the series (except for the case of electricity). The short-run dynamics of the interested variables were tested, indicating the existence of granger causality from oil consumption to GDP, but no causation existed running in any direction between gas and GDP and between aggregate energy consumption and GDP. In the long run, the result of the study showed that disaggregated energy consumption causes GDP and that there is a bidirectional causal relationship between aggregated energy consumption and GDP. On the other hand, GDP causes electricity consumption, using a VAR specification. The study recommended that policy makers in Tunisia should give priority to the reconstruction of infrastructure development of the aggregated and disaggregated energy consumption as this would force the sustainable economic growth in Tunisia.

[31] examined whether energy consumption fuels economic growth or vice versa in India for the period 1970 to 2011. Employing the Granger causality technique, the study observed that economic growth fuels more demand for lignite and electricity consumption. In contrast, the forecast variance decomposition of the VAR estimate suggested a bidirectional influence between electricity consumption and economic growth and between lignite consumption and economic growth while a unidirectional influence from GDP growth to natural gas consumption was also observed.

\section{Research Methodology}

\subsection{Variable Measurement and Data Sources}

This study examined empirically the nexus between components of energy consumption and sectoral output. The components of energy consumption used for this study include gas, coal, electricity and crude oil. With respect to sectoral output, the outputs of agriculture; manufacturing; Building and Construction; Wholesale and Retail and the service sector are utilized. Data on Agriculture (AGR), Building and Construction (BOC), Wholesale and Retail (WOR), Service (SER), Electricity (ELE), and Crude oil 
(CRD) are sourced from the Central Bank of Nigeria statistical bulletin while data on gas (GAS) and coal (COL) consumption are sourced from the International Energy Association (IEA) statistical bulletin. All variables are transformed in logarithms.

\subsection{Econometric Method}

This study commenced its empirical analysis by examining the stationarity status of the time series, which is then followed by the co-integration test. If the series are observed to be integrated of different orders, a linear combination of the series may be co-integrated [32]. Furthermore, [33] pointed out that a linear combination of two or more non-stationary series may be stationary. If such a stationary linear combination exists, the non-stationary time series are said to be co-integrated. The stationary linear combination is called the co-integrating equation and may be interpreted as a long-run equilibrium relationship among the variables. To examine the existence of co-integration among the series, the Engel-Granger technique is utilized. The Engel-granger technique is observed to be most suitable for testing co-integration between two variables as against the Johansen co-integration test which is adopted when the model is a multi-variate model given the possibility of having more than one co-integrating vector. Since this study only considers two-variable scenarios (such as electricity consumption and agricultural output) then the problem of multi co-integration does not exist [34]. Based on the evidence from the co-integration test, the appropriate causality test (that is whether it would be specified in VAR or VECM model) would be applied to examine the nexus between components of energy consumption and sectoral output.

\subsection{Model Specification}

Drawing from the above argument, if the pairs of variables (such as electricity consumption and agricultural output) are not co-integrated, then a VAR model specified of equations (1) and (2) is utilized.

$$
\begin{aligned}
& Y_{t}=\alpha_{Y}+\sum_{i=1}^{n} \beta_{i} Y_{t-i}+\sum_{i=1}^{n} \delta_{i} X_{t-i}+\varepsilon_{Y t} \\
& X_{t}=\alpha_{X}+\sum_{i=1}^{n} \beta_{i} Y_{t-i}+\sum_{i=1}^{n} \delta_{i} X_{t-i}+\varepsilon_{X t}
\end{aligned}
$$

where $Y_{t}$ refers to sectoral output (that is AGR; MAN; BOC; WOR and SER), $X_{t}$ refers to components of energy consumption (that is, COL; GAS; ELE and CRD), $\alpha_{Y}$ and $\alpha_{X}$ are constant terms while $\varepsilon_{Y t}$ and $\varepsilon_{X t}$ are the are the Gaussian residuals.

On the other hand, if the variables are co-integrated then, the VAR model must include an error correction term. EngelGranger (1987) cautioned that the Granger causality test, which is conducted in the first differences of variables through a vector auto-regression (VAR) would be misleading in the presence of co-integration. Thus, the inclusion of an additional variable to the VAR system, such as the error correction term would help capture the long run relationship among the variables. To this end, an augmented form of causality test involving the error correction term in a bi-variate form is expressed in a Vector Error-Correction Model (VECM) as:

$$
\begin{gathered}
\Delta Y_{t}=\alpha_{Y}+\sum_{i=1}^{n} \beta_{i} \Delta Y_{t-i}+\sum_{i=1}^{n} \delta_{i} \Delta X_{t-i}+\lambda E C T_{t-1}+\varepsilon_{Y t} \\
\Delta X_{t}=\alpha_{X}+\sum_{i=1}^{n} \beta_{i} \Delta Y_{t-i}+\sum_{i=1}^{n} \delta_{i} \Delta X_{t-i}+\lambda E C T_{t-1}+\varepsilon_{X t}
\end{gathered}
$$

where $E C T_{t-1}$ is the error correction term.

\section{Empirical Result}

\subsection{Unit Root Test}

Table 1. Unit Root Test.

\begin{tabular}{lllllll}
\hline \multicolumn{2}{l}{ Augmented Dickey-Fuller (ADF) Test } & \multicolumn{5}{l}{ Phillip-Perron (PP) Test } \\
\hline Variables & Level & $1^{\text {st }} / 2^{\text {nd }}$ Diff & Status & Level & $1^{\text {st }} / 2^{\text {nd }}$ Diff & Status \\
Lagr & $-4.7868^{*}$ & - & $\mathrm{I}(0)$ & -4.2074 & - & $\mathrm{I}(0)$ \\
Lboc & -1.0251 & $-9.8655^{*}$ & $\mathrm{I}(1)$ & -1.1104 & $-7.7208^{*}$ & $\mathrm{I}(1)$ \\
Lman & -1.10898 & $-13.1683^{*}$ & $\mathrm{I}(2)$ & $-4.0492^{*}$ & - & $\mathrm{I}(0)$ \\
Lser & -2.3983 & $-19.4817^{*}$ & $\mathrm{I}(1)$ & -2.3577 & $-15.0173^{*}$ & $\mathrm{I}(1)$ \\
Lwor & $-3.0794^{* *}$ & - & $\mathrm{I}(0)$ & $-2.9843^{* *}$ & - & $\mathrm{I}(0)$ \\
Lcol & -0.8578 & $-8.0385^{*}$ & $\mathrm{I}(1)$ & -1.8797 & $-17.4196^{*}$ & $\mathrm{I}(1)$ \\
Lcrd & -1.6546 & $-5.3134^{*}$ & $\mathrm{I}(1)$ & -1.7421 & $-5.2994^{*}$ & $\mathrm{I}(1)$ \\
Lele & -0.9233 & $-8.9750^{*}$ & $\mathrm{I}(1)$ & -0.6921 & $-8.3109^{*}$ & $\mathrm{I}(1)$ \\
Lgas & -2.9385 & $-8.2801^{*}$ & $\mathrm{I}(1)$ & -2.9385 & $-8.0769^{*}$ & $\mathrm{I}(1)$ \\
\hline
\end{tabular}

Note: $*=1 \%$ and $* *=5 \%$ significance level.

The stationarity tests on the variables were carried out using the Augmented Dickey-Fuller (ADF) and the PhillipPerron tests and the result are presented in Table 1. Using the ADF test estimate on the left hand of the Table 1, it was observed that Iboc, Iser, Icol, Icrd, Iele and Igas were not stationary at levels but were stationary at first difference, implying that the variables were integrated of order one. In addition, the variables lagr, and lwor were observed to be stationary at levels, implying that they are integrated of order zero. With respect to variable lman, the ADF and PP tests 
give conflicting results on the order of integration. The ADF test indicated that the variable is integrated of order two while the PP test showed it to be integrated of order zero. However, for the purpose of this study, the variable lman, would be treated as an I (0) variable, in line with the PhillipsPerron estimate. With respect to other variables, the findings of the ADF test were confirmed with that of the PhillipPerron result on the other column of Table 1.

\subsection{Co-Integration}

Table 2. Co-integration Estimate Coal Consumption Vs Sectoral Output.

\begin{tabular}{lll}
\hline Dependent Variables & tua-statistics & z-statistics \\
\hline lcol & $-4.3692(0.0083)^{*}$ & $-22.2195(0.0093)^{*}$ \\
lagr & $-6.4331(0.0001)^{*}$ & $-25.9908(0.0022)^{*}$ \\
lcol & $-3.2533(0.0888)$ & $-15.5567(0.0759)$ \\
lman & $-5.1050(0.0014)^{*}$ & $-21.7531(0.0109)^{* *}$ \\
lcol & $-3.3834(0.0693)$ & $-17.0461(0.0496)^{* *}$ \\
lboc & $-2.7477(0.2111)$ & $-14.2704(0.1075)$ \\
lcol & $-3.5352(0.0512)$ & $-17.5153(0.0431)^{* *}$ \\
lwor & $-4.2126(0.0118)^{*}$ & $-186732(0.0302)^{* *}$ \\
lcol & $-4.3956(0.0078)^{*}$ & $-23.5330(0.4579)$ \\
lser & $-4.4713(0.0065)^{*}$ & $-22.1410(0.0095)^{*}$ \\
\hline
\end{tabular}

Note: values in () are probability values while $* / * *$ implies $1 / 5$ percent significance value respectively.

Sequel to the stationary tests, the study proceeds to examine the existence of co-integration between the pairs of variables via the Engel-Granger co-integration techniques. With respect to the existence of co-integration between coal consumption and sectoral output (Table 2), it was observed that there exist two co-integrations equations between coal consumption (lcol) and agricultural output (lagr). The tuastatistics and the z-statistics for this pair of variable unanimously rejected the null of no co-integration at $1 \%$ level, implying the existence of co-integration between coal consumption and agricultural output. Furthermore, one cointegrating equation was observed between lcol and lman; lcol and lwor; lcol and lser. The tua-statistics and the zstatistics for these pairs of variables rejected the null of no co-integration at 5\% level, implying the existence of a long run relationship between the variables. However, with respect to the pair of variable lcol and lboc, no co-integration was observed. Although, the z-statistics of the pair of variable (lcol and lboc) with lcol as the dependent variable rejected the null hypothesis of no co-integration at 5\% level, the inability of the tua-statistics to reject the null hypothesis at this level implied the absence of co-integration between the following pairs of variables.

On co-integration between gas consumption and sectoral output (Table 3 ), it was observed that there exist only one cointegrating equation between gas consumption (lgas) and agricultural output (lagr) with lagr as dependent variable. For the other pair of variables, no co-integration relationship was observed, the Engel-Granger tua-statistics and z-statistics from the co-integrating estimate clearly failed to reject the null of no co-integration at 5\% level.
Table 3. Co-integration Estimate Gas Consumption Vs Sectoral Output.

\begin{tabular}{lll}
\hline Dependent Variables & tua-statistics & z-statistics \\
\hline lgas & $-2.6006(0.2629)$ & $-13.1377(0.1439)$ \\
lagr & $-3.6745(0.0385)^{* *}$ & $-18.2230(0.0347)^{* *}$ \\
lgas & $-2.0284(0.5221)$ & $-8.7688(0.0759)$ \\
lman & $-3.2485(0.0896)$ & $-15.9041(0.0688)$ \\
lgas & $-2.1676(0.4533)$ & $-6.5560(0.5684)$ \\
lboc & $-0.6418(0.9513)$ & $-2.3145(0.9166)$ \\
lgas & $-1.6311(0.7108)$ & $-7.1269(0.5175)$ \\
lwor & $-1.6399(0.7070)$ & $-7.6899(0.4691)$ \\
lgas & $-1.9582(0.5569)$ & $-9.3945(0.3382)$ \\
lser & $-1.4079(0.7975)$ & $-6.8780(0.5395)$ \\
\hline
\end{tabular}

Note: values in () are probability values while $* / * *$ implies $1 / 5$ percent significance value respectively.

Table 4. Co-integration Estimate Electricity Consumption Vs Sectoral Output.

\begin{tabular}{lll}
\hline Dependent Variables & tua-statistics & z-statistics \\
\hline lele & $-6.5507(0.0000)^{*}$ & $-30.9704(0.0002)^{*}$ \\
lagr & $-14.1151(0.0000)^{*}$ & $-38.4323(0.0000)^{*}$ \\
lele & $-4.9269(0.0022)^{*}$ & $-24.7271(0.0037)^{*}$ \\
lman & $-1.5784(0.7332)$ & $-13.1135(0.1135)$ \\
lele & $-2.7066(0.2249)$ & $-11.9989(0.1901)$ \\
lboc & $-2.8374(0.1833)$ & $-13.7252(0.1239)$ \\
lele & $-5.9864(0.0002)^{*}$ & $-29.5372(0.0005)^{*}$ \\
lwor & $-9.0522(0.0000)^{*}$ & $-35.6078(0.0000)^{*}$ \\
lele & $-5.7081(0.0003)^{*}$ & $-29.4581(0.0005)^{*}$ \\
lser & $-7.0132(0.0000)^{*}$ & $-32.2431(0.0001)^{*}$ \\
\hline
\end{tabular}

Note: values in () are probability values while $* / * *$ implies $1 / 5$ percent significance value respectively.

With respect to the existence of co-integration between electricity consumption (lele) and sectoral output (Table 4), it was observed that there exist two co-integrating equations between the following pair of variables: lele and lagr; lele and lwor; lele and lser. The tua-statistics and the z-statistics for these pairs of variables unanimously rejected the null of no co-integration at $1 \%$ level, implying the existence of cointegration between the pair of variables. In addition, one cointegrating equation was observed between lele and lman with lele as dependent variable. The tua-statistics and the $\mathrm{z}$ statistics for this pair of variable also rejected the null of no co-integration at $1 \%$ level, implying the existence of a long run relationship between the variables. However, the pair of variable lele and lboc showed no evidence co-integration, the tua-statistics and z-statistics from the Engel-Granger cointegrating estimate failed to reject the null of no cointegration at $5 \%$ level.

Finally, with respect to the co-integration estimate between pair of variables concerning crude oil consumption and sectoral output (see Table 5), no evidence of co-integration was observed. The tua and z-statisti for all pair of variables unanimously failed to reject the null of no co-integration at $5 \%$ level. 
Table 5. Co-integration Estimate Crude Oil Consumption Vs Sectoral Output.

\begin{tabular}{lll}
\hline Dependent Variables & tua-statistics & z-statistics \\
\hline lcrd & $-1.9267(0.5727)$ & $-8.2058(0.4248)$ \\
lagr & $0.0819(0.9908)$ & $0.1106(0.9900)$ \\
lcrd & $-2.0502(0.5115)$ & $-8.8364(0.3761)$ \\
lman & $-1.7216(0.6710)$ & $-13.0593(0.1365)$ \\
lcrd & $-2.2096(0.4335)$ & $-10.4032(0.2710)$ \\
lboc & $-0.4912(0.9645)$ & $-1.2759(0.9608)$ \\
lcrd & $-1.6547(0.7006)$ & $-5.3693(0.6775)$ \\
lwor & $-3.4623(0.0593)$ & $-7.8183(0.4584)$ \\
lcrd & $-1.5222(0.7556)$ & $-5.0846(0.7036)$ \\
lser & $0.4360(0.9966)$ & $0.5731(0.9943)$ \\
\hline
\end{tabular}

Note: values in () are probability values while $* / * *$ implies $1 / 5$ percent significance value respectively.

\subsection{Causality Estimate}

Based on the co-integration results, the causal nexus between the pair of variables that are not co-integrated were analyzed using equations (1) and (2) while the causal nexus between co-integrated variables were analyzed via equations (3) and (4). The results of the causality estimate were presented in sub-sections below.

\subsubsection{Causality Estimate on Coal Consumption and Sectoral Output}

Based on the co-integration results, the nexus between lboc and lcol is analyzed using the VAR bi-variate granger causality estimate while the causal nexus between the following pair of variables (lcol and lagr; lcol and lman; lcol and lwor; lcol and lser) were analyzed using the VECM bivariate approach. Base on the VAR bi-variate estimate on Table $6 \mathrm{a}$, it was revealed that there exists a unidirectional causation from coal consumption (lcol) to building and construction (lboc) output while no feedback was observed.

The VECM causality estimate on coal consumption and agricultural output (Table 6b) showed that the error correction term for co-integration equation with agricultural output (lagr) as dependent variable was observed to be significant at 5\%, implying that there exists long run causation from coal consumption to agricultural output. Also, the error term had its expected negative sign and the coefficient value of -0.14 indicated that the relationship between coal consumption and agricultural output will converge towards its long-run equilibrium at a much slow pace. In contrast, the short run causality estimate with agricultural output as dependent variable showed no evidence of causality from coal consumption to agricultural output. In addition, with coal consumption as dependent variable, no evidence of causation was observed in the long and short run from agricultural output to coal consumption. The implication of the above is that there exists unidirectional long run causality from coal consumption to agricultural output.
Table 6a. Causality Estimates between Coal Consumption and Sectoral Output.

\begin{tabular}{lll}
\hline $\mathbf{H}_{\mathbf{0}}$ & $\begin{array}{l}\text { F-Stat (Prob } \\
\text { Value) }\end{array}$ & Conclusion \\
\hline $\mathrm{lboc} \rightarrow \mathrm{lcol}$ & $1.4351(0.2578)$ & No causality from lboc $\rightarrow$ lcol \\
$\mathrm{lcol} \rightarrow \mathrm{lboc}$ & $6.5746(0.0053) *$ & Unidirectional causality from lcol $\rightarrow \mathrm{lboc}$ \\
\hline
\end{tabular}

Note: values in () are probability values while * implies 1 percent significance value.

Table 6b. Causality Estimates between Coal Consumption and Sectoral Output.

\begin{tabular}{llll}
\hline Dependent & \multicolumn{2}{l}{ Independent Variable } \\
\cline { 2 - 4 } Variables & $\Delta$ LOutput & $\Delta$ LCOL & ECT $_{\text {t- } 1}$ \\
\hline$\Delta$ LAGR & - & $0.0371[1.0860]$ & $-0.1360[-2.7291]^{* *}$ \\
$\Delta$ LCOL & $0.3955[0.2138]$ & - & $-0.6037[-1.4670]$ \\
$\Delta$ LMAN & - & $0.0134[0.6973]$ & $0.0108[1.9589]$ \\
$\Delta$ LCOL & $0.1669[0.1314]$ & - & $0.0328[0.6221]$ \\
$\Delta$ LWOR & - & $0.0342[2.5088]^{* *}$ & $-0.0183[-2.2176]^{* *}$ \\
$\Delta$ LCOL & $-0.6904[-0.3468]$ & & $-0.1042[-0.8987]$ \\
$\Delta$ LSER & & $0.0118[0.4693]$ & $-0.0658[-1.7877]$ \\
$\Delta$ LCOL & $3.0949[1.8552]$ & & $-0.1610[-0.4793]$ \\
\hline
\end{tabular}

Note: values in [] are t-values while $* / * *$ implies $1 / 5$ percent significance value respectively.

$\Delta$ LOutput implies $\triangle \mathrm{LAGR} ; \triangle \mathrm{LMAN} ; \Delta \mathrm{LWOR}$ or $\Delta \mathrm{LSER}$.

With respect to the nexus between coal consumption and manufacturing output, the error correction term for cointegration equation with coal consumption (col) and manufacturing output as dependent variables were insignificant at $5 \%$, implying no evidence of causation between coal consumption (col) and manufacturing output in the long run. In the short run, no evidence of causality was also observed between coal consumption to manufacturing output. This result suggests that there exist no causation between coal consumption and manufacturing output. The result of the VECM causality estimate obtained between coal consumption and manufacturing output in the long run and short run also applied to the nexus between coal consumption and service output.

On the nexus between coal consumption and wholesale and retail output, the error correction term for co-integration equation with wholesale and retail output (lwor) as dependent variable was also observed to be significant at 5\%, implying the existence of long run causation from coal consumption to wholesale and retail output. Also, the error term had its expected negative sign and the coefficient value of -0.02 indicated that the relationship between coal consumption and wholesale and retail output will converge towards its longrun equilibrium at a very much slow pace. Also, the short run causality estimate with wholesale and retail output as dependent variable showed the existence of causality from coal consumption to wholesale and retail output. In addition, with coal consumption as dependent variable, no evidence of causation was observed either in the long and short run from wholesale and retail output to coal consumption. The implication of the above is that there exists unidirectional causality from coal consumption to wholesale and retail output in long and short run. 


\subsubsection{Causality Estimate on Gas Consumption and Sectoral Output}

Base on the VAR bi-variate estimate on Table 7a, it was revealed that there exists a unidirectional causation from gas consumption to manufacturing; building and construction; and service output while no feedback was observed from any of these sectoral outputs to gas consumption. Furthermore, it was revealed that the null hypothesis that gas consumption (lgas) does not granger-cause wholesale and retail output (lwor) at 5\% significance level could not be rejected. This simply indicates that there exist no evidence of causality from gas consumption to wholesale and retail output and no feedback was also observed.

Table 7a. Causality Estimates between Gas Consumption and Sectoral Output.

\begin{tabular}{|c|c|c|}
\hline $\mathbf{H}_{\mathbf{0}}$ & F-Stat (Prob Value) & Conclusion \\
\hline $\operatorname{lman} \rightarrow$ lgas & $2.5405(0.0998)$ & No causality from lman $\rightarrow$ lgas \\
\hline $\operatorname{lgas} \rightarrow \operatorname{lman}$ & $6.4886(0.0056)^{*}$ & $\begin{array}{l}\text { Unidirectional causality from lgas } \rightarrow \\
\text { lman }\end{array}$ \\
\hline lboc $\rightarrow$ lgas & $1.9468(0.1646)$ & No causality from lboc $\rightarrow$ lgas \\
\hline lgas $\rightarrow$ lboc & $31.6058(0.0000)^{*}$ & $\begin{array}{l}\text { Unidirectional causality from lgas } \rightarrow \\
\text { lboc }\end{array}$ \\
\hline lwor $\rightarrow$ lgas & $3.0095(0.0682)$ & No causality from lwor $\rightarrow$ lgas \\
\hline lgas $\rightarrow$ lwor & $2.1060(0.1437)$ & No causality from lgas $\rightarrow$ lwor \\
\hline lser $\rightarrow$ lgas & $1.6231(0.2182)$ & No causality from lser $\rightarrow$ lgas \\
\hline lgas $\rightarrow$ lser & $3.5934(0.0431)^{* *}$ & $\begin{array}{l}\text { Unidirectional causality from lgas } \rightarrow \\
\text { lser }\end{array}$ \\
\hline
\end{tabular}

Note: values in () are probability values while $* / * *$ implies $1 / 5$ percent significance value respectively.

Table 7b. Causality Estimates between Gas Consumption and Sectoral Output.

\begin{tabular}{llll}
\hline Dependent & \multicolumn{3}{l}{ Independent Variable } \\
\cline { 2 - 4 } Variables & $\Delta$ LAGR & $\Delta$ LGAS & ECT $_{\mathbf{t}-1}$ \\
\hline$\Delta$ LAGR & - & $-0.0141[-0.2020]$ & $-0.0034[-0.8010]$ \\
$\Delta$ LGAS & $0.7420[2.5309]^{* *}$ & - & $0.0283[2.5309]$ \\
\hline
\end{tabular}

values in [] are t-values while ** implies 5 percent significance value.

The VECM causality estimate (Table 7b) on the nexus between gas consumption (lgas) and agricultural output (lagr), showed that the error correction term for cointegration equation with gas consumption as dependent variable was significant at $5 \%$, but the error term was without its correct sign (its positive). The short run causality estimate with gas consumption as dependent variable, showed the existence of causation from agricultural output to gas consumption. With agricultural output as dependent variable, no evidence of causation was observed either in the long and short run from gas consumption to agricultural output. This implies that there exists unidirectional causation from agricultural output to gas consumption in short run.

\subsubsection{Causality Estimate on Electricity Consumption and Sectoral Output}

On the causal nexus between electricity consumption and building and construction output, the VAR bi-variate causality estimate on Table $8 \mathrm{a}$ showed that there exists bidirectional causation between electricity consumption and building and construction output at 1\% significant level.

Table 8a. Causality Estimates between Electricity Consumption and Sectoral Output.

\begin{tabular}{lll}
\hline $\mathbf{H}_{\mathbf{0}}$ & F-Stat (Prob Value) & Conclusion \\
\hline lboc $\rightarrow$ lele & $7.7726(0.0025)^{*}$ & Bidirectional causality between \\
lele $\rightarrow$ lboc & $24.2388(0.0000)^{*}$ & lboc and lele \\
\hline
\end{tabular}

Note: values in () are probability values while * implies 1 percent significance value.

Table 8b. Causality Estimates between Electricity Consumption and Sectoral Output.

\begin{tabular}{llll}
\hline Dependent & \multicolumn{2}{l}{ Independent Variable } & \\
\cline { 2 - 4 } Variables & $\Delta$ LOutput & $\Delta$ LELE & ECT $_{\mathbf{t}-1}$ \\
\hline$\Delta \mathrm{LAGR}$ & - & $0.02111[0.9135]$ & $0.1867[1.2699]$ \\
$\Delta \mathrm{LELE}$ & $-0.0564[-0.2201]$ & - & $0.3984[2.8251]^{*}$ \\
$\Delta \mathrm{LMAN}$ & - & $-0.1080[-0.6676]$ & $-0.2648[-2.1509]^{* *}$ \\
$\Delta \mathrm{LELE}$ & $0.4901[2.3944]^{* *}$ & - & $0.2711[1.6977]$ \\
$\Delta \mathrm{LWOR}$ & - & $0.0047[0.0420]$ & $-0.1474[-3.0490]^{*}$ \\
$\Delta \mathrm{LELE}$ & $0.3046[0.7691]$ & & $0.0562[0.6306]$ \\
$\Delta \mathrm{LSER}$ & & $0.2140[1.3679]$ & $0.0644[0.8077]$ \\
$\Delta \mathrm{LELE}$ & $0.0473[0.1886]$ & & $0.2369[2.2624]^{* *}$ \\
\hline
\end{tabular}

values in [] are t-values while $* * *$ implies $1 / 5$ percent significance value respectively.

$\Delta$ LOutput implies $\triangle \mathrm{LAGR} ; \triangle \mathrm{LMAN} ; \triangle \mathrm{LWOR}$ or $\triangle \mathrm{LSER}$.

On the nexus between electricity consumption and manufacturing output, the VECM estimate (Table 8b) showed that the error correction term for co-integration equation with manufacturing output (lman) as dependent variable was significant at $5 \%$, implying the existence of long run causation from electricity consumption to manufacturing output. The error term had its expected negative sign and the coefficient value of -0.26 indicated that the relationship between electricity consumption and manufacturing output will converge towards its long-run equilibrium at a slow pace. The short run causality estimate with manufacturing output as dependent variable showed no evidence of causality from electricity consumption to manufacturing output. With electricity consumption as dependent variable, no evidence of causality was observed from manufacturing output to electricity consumption in the long run. However, in the short run manufacturing output was found to granger cause electricity consumption. The implication of the above is that there exists bidirectional causation between electricity consumption and manufacturing output with causation running from electricity consumption to manufacturing output in the long run and from manufacturing output to electricity consumption in the short run.

On the nexus between agricultural output and electricity consumption, the VECM estimate (Table 8b) showed that with agricultural output as dependent variable no evidence of either long run or short run causality was observed from electricity consumption to agricultural output. With electricity consumption as dependent variable, the error correction term for co-integrating equation was significant at $5 \%$, but without its correct sign (its positive). Furthermore, the short run causality estimate with electricity consumption as dependent variable showed no evidence of causation from gross domestic 
product to electricity consumption. Overall, the result of the causality estimate obtained between electricity consumption and agricultural output in the long run and short run also applied to the nexus between electricity consumption and service output. The implication of this result is that there exists no causality between: electricity consumption and agricultural output; electricity consumption and service output, both in the long and short run.

On the causal nexus between electricity consumption and wholesale and retail output (Table $8 \mathrm{~b}$ ) with wholesale and retail output as dependent variable, it was revealed that the error correction term for co-integration equation was significant at $1 \%$, implying that there exists long run causation from electricity consumption to wholesale and retail output. The error term had its expected negative sign and the coefficient value of -0.15 indicated that the relationship between electricity consumption and wholesale and retail output will converge towards its long-run equilibrium at a slow speed. In contrast, the short run causality estimate with wholesale and retail as dependent variable showed no evidence of causality from electricity consumption to wholesale and retail output. With electricity consumption as dependent variable, no evidence of causation was observed from wholesale and retail output to electricity consumption product both in long and short run. The implication of the above is that there exists unidirectional long run causality from electricity consumption to wholesale and retail output.

\subsubsection{Causality Estimate on Crude Oil Consumption and Output Growth}

Given the non-existence of co-integration between crude oil consumption and sectoral output, the causality test was estimated using the VAR bi-variate models. The causality estimate as presented on Table 9 showed there exists a unidirectional causation from building and construction output to crude oil consumption while no feedback was observed from crude oil consumption to building and construction output. Furthermore, it was revealed that the null hypothesis that crude oil consumption (lcrd) does not granger-cause agriculture (lagr), manufacturing (lman), wholesale and retail, and the service output at 5\% significance level could not be rejected. This simply indicates that there exist no evidence of causality from crude oil consumption to agriculture (lagr), manufacturing (lman), wholesale and retail, and the service output and no feedback was observed from these outputs to crude oil consumption.

Table 9. Causality Estimates between Crude Oil Consumption and Output Growth.

\begin{tabular}{lll}
\hline $\mathbf{H}_{\mathbf{0}}$ & F-Stat (Prob Value) & Conclusion \\
\hline lagr $\rightarrow$ lcrd & $1.6147(0.2198)$ & No causality from lagr $\rightarrow$ lcrd \\
lcrd $\rightarrow$ lagr & $1.1993(0.3188)$ & No causality from lcrd $\rightarrow$ lagr \\
lman $\rightarrow$ lcrd & $2.1399(0.1396)$ & No causality from lman $\rightarrow$ lcrd \\
lcrd $\rightarrow$ lman & $0.0972(0.9078)$ & No causality from lcrd $\rightarrow$ lman \\
& Unidirectional causality from \\
lboc $\rightarrow$ lcrd & $4.7227(0.0186)^{* *}$ & lboc $\rightarrow$ lcrd \\
lcrd $\rightarrow$ lboc & $0.5637(0.5765)$ & No causality from lcrd $\rightarrow$ lboc \\
lwor $\rightarrow$ lcrd & $1.9114(0.1697)$ & No causality from lwor $\rightarrow$ lcrd \\
\hline
\end{tabular}

\begin{tabular}{lll}
\hline $\mathbf{H}_{\mathbf{0}}$ & F-Stat (Prob Value) & Conclusion \\
\hline $\mathrm{lcrd} \rightarrow$ lwor & $0.9408(0.4042)$ & No causality from lcrd $\rightarrow$ lwor \\
$\mathrm{lser} \rightarrow$ lcrd & $1.7212(0.2002)$ & No causality from lser $\rightarrow$ lcrd \\
$\mathrm{lcrd} \rightarrow$ lser & $1.0505(0.3653)$ & No causality from lcrd $\rightarrow$ lser \\
\hline
\end{tabular}

Note: ** implies 5 percent significant level

A summary of the causal nexus between components of energy consumption and sectoral output is presented on Table 10 below. A glance at the table revealed that coal consumption granger cause agricultural and wholesale and retail outputs in the long run while in the short run, coal consumption also granger caused building and construction, and wholesale and retail outputs. With respect to gas consumption, a unidirectional causation was observed from agricultural output to gas consumption in the long run while in the short run a unidirectional causation was observed from gas consumption to manufacturing; building and construction; and the service sectors. Electricity consumption was observed to granger cause manufacturing and wholesale and retail outputs while in the short run a unidirectional causality was observed from manufacturing output to electricity consumption. In addition, bidirectional causation was observed between electricity consumption and building and construction sector in the short. Finally, a unidirectional was observed from building and construction sector to crude oil consumption in the short run.

Table 10. Summary of Short and Long run Causality between Sectoral Output and Components of Energy.

\begin{tabular}{|c|c|c|c|c|c|c|}
\hline \multirow{2}{*}{$\begin{array}{l}\text { COMPONENTS } \\
\text { OF ENERGY }\end{array}$} & \multirow{2}{*}{ Causality } & \multicolumn{5}{|c|}{ SECTORS } \\
\hline & & AGR & MAN & BOC & WOR & SER \\
\hline \multirow{2}{*}{ COAL } & Long-run & $\rightarrow$ & - & - & $\rightarrow$ & - \\
\hline & Short-run & - & - & $\rightarrow$ & $\rightarrow$ & - \\
\hline \multirow{2}{*}{ GAS } & Long-run & $\leftarrow$ & - & - & - & - \\
\hline & Short-run & - & $\rightarrow$ & $\rightarrow$ & - & $\rightarrow$ \\
\hline \multirow{2}{*}{ ELECTRICITY } & Long-run & - & $\rightarrow$ & - & $\rightarrow$ & - \\
\hline & Short-run & - & $\leftarrow$ & $\leftrightarrow$ & - & - \\
\hline \multirow{2}{*}{ CRUDE OIL } & Long-run & - & - & - & - & - \\
\hline & Short-run & - & - & $\leftarrow$ & - & - \\
\hline
\end{tabular}

Notes: $\rightarrow$ implies unidirectional causality from components of energy consumption to sectoral output;

$\leftarrow$ implies unidirectional causality from sectoral output to components of energy consumption;

$\leftrightarrow$ implies bidirectional causality between sectoral output and components of energy consumption.

\section{Conclusions and Policy Recommendations}

This study examined a one-to-one causal nexus between components of energy consumption (gas, coal, electricity and crude oil) and outputs of the different sectors (agriculture, manufacturing, building and construction, wholesale and retail and service sector) of the Nigerian economy for the period covering 1980 to 2014. Given the focus of this study, the EngelGranger co-integration test was utilized. Pair of variables that were not co-integrated was analyzed using the VAR bi-variate model while the pair of variables that were co-integrated were analyzed using the VECM bi-variate model. Utilizing these 
methods, it was observed that there exists different direction of causality between components of energy consumption and output of the different sectors of the economy. Thus, this study recommends that energy policies should be sector specific, taking into cognizance the components of energy consumption that influence the output growth of individual sectors or components of energy consumption that are being influenced by the output growth of these sectors.

\section{References}

[1] Binh, P. T. (2011) 'Energy Consumption and Economic Growth in Vietnam: Threshold Co-integration and Causality Analysis', International Journal of Energy Economics and Policy, Vol. 1, No. 1, pp. 1-17.

[2] Kaplan M., Ozturk, I. and Kalyoncu, H. (2011) 'Energy Consumption and Economic Growth in Turkey: Cointegration and Causality Analysis', Romanian Journal of Economic Forecasting, Vol. 14, No. 2, pp. 31-41.

[3] Noor, S. and Siddiqui, M. W. (2010) 'Energy Consumption and Economic Growth in South Asian Countries: A Cointegrated Panel Analysis', International Journal of Human and Social Sciences, Vol. 5, No. 14, pp. 921-926.

[4] Stern, D. I. (2000) 'A Multivariate Co-integration Analysis of the Role of Energy in the US Economy', Energy Economics, Vol. 22, No. 2, pp. 267-283.

[5] Adeniran, O. (2009) 'Does Energy Consumption Cause Economic Growth? An Empirical Evidence from Nigeria', CEPMLP (Centre for Energy, Petroleum and Mineral Law and Policy) Annual Review (CAR), 2009.

[6] Omisakin, O. A. (2008) 'Energy Consumption and Economic Growth in Nigeria: A Bounds Testing Co-integration Approach', Journal of Economic Theory, Vol. 2, No. 4, pp. 18-23.

[7] Chen S. T., Kuo, H. I. and Chen, C. (2007) 'The Relationship between GDP and Electricity Consumption in 10 Asian Countries', Energy Policy, Vol. 35, No. 4, pp. 2611-2621.

[8] Abosedra, S. and Baghestani, H. (1989) 'New Evidence on the Causal Relationship between United States Energy Consumption and Gross National Product', Journal of Energy and Development, Vol. 14, No. 2, pp. 285-292.

[9] Erol, U. and Yu, E. S. H. (1987) 'On the Causal Relationship between Energy and Income for Industrializing Countries', Journal of Energy and Development, Vol. 13, No. 1, pp. 113-122.

[10] Kraft, J. and Kraft, A., (1978) On the Relationship between Energy and GNP, Journal of Energy and Development, Vol. 3, No. 2, pp. 401-403.

[11] Akinlo, A. E. (2009) 'Electricity Consumption and Economic Growth in Nigeria: Evidence from Co-integration and Cofeature Analysis', Journal of Policy Modelling, Vol. 31, No. 5, pp. 681-693.

[12] Khan, M. A. and Ahmed, U. (2009) 'Energy Demand in Pakistan: A Disaggregate Analysis', MPRA Paper, No. 15369, University Library of Munich, Germany.

[13] Narayan, P. K. and Singh, B. (2007) 'The Electricity Consumption and GDP Nexus for the Fiji Islands', Energy
Economics, Vol. 29, No. 6, pp. 1141-1150.

[14] Altinay, G. and Karagol, E. (2005) 'Electricity Consumption and Economic Growth: Evidence from Turkey', Energy Economics, Vol. 27, No. 6, pp. 849-856.

[15] Wolde-Rufael, Y. (2004) 'Disaggregate Energy Consumption and GDP, the Experience of Shangai 1952-1999', Energy Economics, Vol. 26, No. 1, pp. 69-75.

[16] Shiu, A. and Lam, P. L. (2004) 'Electricity Consumption and Economic Growth in China', Energy Policy, Vol. 32, No. 1, pp. 47-54.

[17] Yoo, S. H. (2005) 'Electricity Consumption and Economic Growth: Evidence from Korea', Energy Policy, Vol. 33, No. 12, pp. 1627-1632.

[18] Yoo, S. H. (2006) 'The Causal Relationship between Electricity Consumption and Economic Growth in the ASEAN Countries', Energy Policy, Vol. 34, No. 18, pp. 35733582 .

[19] Nwosa, P. I. and Akinbobola, T. O. (2012) 'Aggregate Energy Consumption and Sectoral Output in Nigeria', African Research Review (ARR), Vol. 6, No. 4, pp. 206-215.

[20] Liew, V. K., Nathan, T. M. and Wong, W. (2012) 'Are Sectoral Outputs in Pakistan Led by energy Consumption?' Economic Bulletin, Vol. 32, No. 3, pp. 2326-2331.

[21] Chebbi, H. E. and Boujelbene, Y. (2008) 'Agriculture and Non-Agriculture Outputs and Energy Consumption in Tunisia: Empirical Evidences from Co-integration and Causality', 12th Congress of the European Association of Agriculture Economists - EAAE 2008.

[22] Ogunleye, E. O. and Ayeni, R. K. (2012) 'Energy Demand in Nigeria: A Disaggregate Analysis', International Research Journal of Finance and Economics, Issue 86 (March), pp. 5262 .

[23] Odularu, G. O. and Okonkwo, C. (2009) 'Does Energy Consumption Contribute to Economic Performance? Empirical Evidence from Nigeria', East-West Journal of Economics and Business, Vol. XII, No. 2, pp. 43-79.

[24] Qazi, A. Q., Ahmed K. and Mudassar, M. (2012) 'Disaggregate Energy Consumption and Industrial Output in Pakistan: An Empirical Analysis', Economics Discussion Paper, $\quad$ No. 29. http://www.economicsejournal.org/economics/discussionpapers/2012-29 (Accessed April 10, 2015).

[25] Aliero, H. M. and Ibrahim, S. S. (2012) 'The Relationship between Energy Consumption and Economic Growth in Nigeria: A Causality Analysis', International Journal of Marketing and Technology, Vol. 2, Issue 3, pp. 1-13.

[26] Erbaykal, E. (2008) 'Disaggregate Energy Consumption and Economic Growth: Evidence from Turkey', International Research Journal of Finance and Economics, Issue. 20 (October), pp. 172-179.

[27] Reddy, M. (2008) Energy Consumption and Economic Activity in Fiji', The Journal of Pacific Studies, Vol. 22, No. 1\&2, pp. 81-96.

[28] Syed, A. R., Syed, T. J. \& Mohammed, H. S. (2016) Electricity Consumption and Economic Growth in South Asia, South Asia Economic Journal, Vol. 17, Issue 2, pp. 200-215. 
[29] Eisa, M. \& Khashayar, S. (2016) Aggregate and Disaggregate Energy Consumption Relation with GDP: Evidence for Iran, Iranian Economic Review, Vol. 20, No. 2, pp. 163-174.

[30] Abid, M. \& Mraihi, R. (2015) Disaggregate Energy Consumption Versus Economic Growth in Tunisia: Cointegration and Structural Break Analysis, Journal of the Knowledge Economy, Vol. 6, Issue 4, pp. 1104-1122. doi: 10.1007/s13132-014-0189-4.

[31] Behera, J. (2015) Energy Consumption and Economic Growth in India: A reconciliation of Disaggregate Analysis, Journal of Energy Technologies and Policy, Vol. 5, No. 6, pp. 15-27.

[32] Nwachukwu, T. E. and Odigie, P. (2009) 'What Drives Private
Saving in Nigeria;, A Paper Presented at the Centre for the Study of African Economies (CSAE) Conference, University of Oxford, March 2009. Available at http://www.csae.ox.ac.uk/conferences/2009-EDiA/papers/502Nwachukwu.pdf [Accessed May 15, 2013].

[33] Engle, R. F. and Granger, C. W. J. (1987) 'Co-integration and Error Correction: Representation, Estimation and Testing', Econometrica, Vol. 55, No. 2, pp. 251-276.

[34] Nwosa, P. I. (2012) 'Domestic Fuel Price and the Nigerian Macroeconomy', African Journal of Economic and Sustainable Development (AJESD), Vol. 1, No. 4, pp. 353365. 